MARTA NIEMIEC

University of Silesia in Katowice

\title{
Work of teachers co-organising the process of education of pupils with special educational needs in the opinions of public school teachers
}

\begin{abstract}
Marta Niemiec, Work of teachers co-organising the process of education of pupils with special educational needs in the opinions of public school teachers. Interdisciplinary Contexts of Special Pedagogy, no. 26, Poznań 2019. Pp. 81-102. Adam Mickiewicz University Press. ISSN 2300-391X. e-ISSN 2658-283X. DOI: https://doi. org/10.14746/ikps.2019.26.04
\end{abstract}

One of the key issues within the area of issues related to contemporary special education is inclusive education. The purpose of the presented article is to analyse the key entities participating in the teaching and upbringing of pupils in the public educational system - the roles, tasks, professional qualifications, predispositions and personality traits of teachers of pupils with special educational needs. The article also presents results of research carried out by the author among teachers at public schools in the Silesian Voivodeship.

KEY WORDS: support teacher, inclusive education, pupil with special educational needs, public educational system

\section{Introduction}

Even though the idea of integration was already promoted in Poland by representatives of Polish special education in the 1970s, among others, by Otton Lipkowski or Aleksander Hulek, discourse, 
disputes, scientific discussions continue until today as to what it actually is, what should inclusive education be like, what are its core conditions? Ever since the times or professors Hulek and Lipkowski, many theoretically and empirically valuable studies on inclusive educations have emerged ${ }^{1}$, in which conditions necessary

${ }^{1}$ Issues of social and education inclusion are touched upon in their papers by, e.g.: Danuta Al-Khamisy, Kształcenie uczniów ze specjalnymi potrzebami edukacyjnymi w powszechnym systemie oświatowym, [in:] Dydaktyka specjalna w przygotowaniu do kształcenia uczniów ze specjalnymi potrzebami edukacyjnymi. Podręcznik akademicki, ed. by J. Głodkowska, Wydawnictwo Akademii Pedagogiki Specjalnej, Warszawa 2012, pp. 113-139; Iwona Chrzanowska, Nauczanie inkluzyjne w doświadczeniach polskich podstawy prawne $i$ społeczne uwarunkowania, "Studia Edukacyjne" 2014, no. 30, pp. 109-117; Beata Cytowska, Przegląd badań empirycznych nad inkluzja w edukacji, „Problemy Edukacji, Rehabilitacji i Socjalizacji Osób Niepełnosprawnych" 2016, no. 22/1, 189-213; Anna Firkowska-Mankiewicz, Idea integracyjnego kształcenia i edukacji właczajacej w polskiej pedagogice, [in:] „Pedagogika specjalna, podręcznik akademicki" vol. 2, ed. by D.D. Smith, A. Firkowska-Mankiewicz, G. Szumski, Wydawnictwo Akademii Pedagogiki Specjalnej, Wydawnictwo Naukowe PWN, Warszawa 2008, pp. 319-346; Zenon Gajdzica, Opinie nauczycieli szkół ogólnodostępnych na temat edukacji włączającej uczniów z lekkim upośledzeniem umysłowym w kontekście toczącej się reformy ksztatcenia specjalnego, [in:] Uczeń z niepetnosprawnościa w szkole ogólnodostępnej, ed. by Z. Gajdzica, Wydawnictwo Wyższej Szkoły Humanitas, Sosnowiec 2011, pp. 56-79; Joanna Głodkowska, W poszukiwaniu modelu edukacji włączającej, „Meritum" 2009, no. 2, pp. 5-8; Zdzisława Janiszewska-Nieścioruk, (Nie)dojrzałość proinkluzyjnych zmian w kształceniu osób z niepetnosprawnościa, "Niepełnosprawność. Dyskursy pedagogiki specjalnej” 2016, no. 22, pp. 47-59; Amadeusz Krause, Wspótczesne paradygmaty pedagogiki specjalnej, Oficyna Wydawnicza „Impuls”, Kraków 2011; Joanna Kruk-Lasocka, Dostrzec dziecko z perspektywy edukacji wtaczającej. Wydawnictwo Naukowe Dolnośląskiej Szkoły Wyższej, Wrocław 2012; Viktor Lechta, Pedagogika inkluzyjna, [in:] Pedagogika. T. 4, Subdyscypliny i dziedziny wiedzy o edukacji, ed. by Bogusław Śliwerski, Gdańskie Wydawnictwo Pedagogiczne, Gdańsk 2010, pp. 321-335; Grzegorz Szumski, Edukacja wtączająca - niedokończony projekt, "Ruch Pedagogiczny” 2014, no. 4, pp. 127-139; Tamara Zacharuk, Wtączająca edukacja, [in:] Encyklopedia Pedagogiczna XXI w., vol. VII, ed. by T. Pilch, Wydawnictwo Akademickie "Żak”, Warszawa 2008, pp. 167-173; Anna Zamkowska, Kompetencje nauczyciela wymagane w pracy z uczniem z niepetnosprawnościa umysłowa w procesie edukacji inkluzyjnej, [in:] Kompetencje pedagoga specjalnego. Aktualne wyzwania teorii i praktyki, ed. by Z. Palak, A. Bujnowska, Wydawnictwo Uniwersytetu Marii Curie-Skłodowskiej, Lublin 2008, pp. 79-88. 
for the emergence of inclusive education are thoroughly analysed in which studies are shown that indicate the reasonability of argumentation both in favour of inclusion as well as against it, and in which diverse hazards and barriers are presented that could prevent the idea of full social or educational participation, the equalisation of changes for persons with special education needs. ${ }^{2}$ At the same time, the majority of authors - researchers and theorists of the discussed issue, unequivocally stress the fact that inclusive education should primarily support the development of all pupils, take into account their diversity, respond to individual needs or design changes in the education system in such a way so that they would not bring all pupils into line, but focus on broadly understood flexibility in education work, with the result being the pupils that need support feeling members of the school. The problematic issue, however, continues to be the lack of semantic clarity of the term of inclusive education, as Iwona Chrzanowska notes in her article when she writes: [...] Polish law does not contain a clear definition of the term. It is frequently treated synonymously to the concept of integration, and at certain times it is understood as a further, higher stage towards normalisation of not only the education situation of disabled persons. ${ }^{3}$ Inclusive education is thus sometimes understood to be a synonym of integration education, a version of integration education or finally an expanded form of integration education. ${ }^{4}$ For instance, the concept of Piero Crispiani describes inclusion as a culture that first encom-

2 The mentioned risks are broadly analysed by Grzegorz Szumski in the article „Edukacja wtączajaca - niedokończony projekt, „Ruch Pedagogiczny” 2014, no. 4, pp. 127-139.

${ }^{3}$ I. Chrzanowska, Nauczanie inkluzyjne w doświadczeniach polskich - podstawy prawne i społeczne uwarunkowania, "Studia Edukacyjne” 2014, no. 30, p. 111.

4 Terminological discourse on the topic is undertaken in the study by Grzegorz Szumski and Anna Firkowska-Mankiewicz in the book: G. Szumski, with A. Firkowska-Mankiewicz, "Wokół edukacji włączającej. Efekty kształcenia uczniów z niepetnosprawnościa intelektualna w stopniu lekkim w klasach specjalnych, integracyjnych i ogólnodostepnych, Wydawnictwo Akademii Pedagogiki Specjalnej, Warszawa 2010, pp. 11-28. 
passes the disabled person as being integrated, and afterwards, contexts that are open and dispositive to integration. Hence, according to the author, inclusion is not a process, but a culture that is connected to an open integration context. Inclusion requires diverse strategies: early diagnosis (in particular functional diagnosis), special education (ortodidactics), an extensive support system, etc. Integration is a process, in which the disabled person effectively participates in social activities and interpersonal relations. ${ }^{5}$ Viktor Lechta in turn, in his study concerning inclusive paedagogy, clearly differentiates between the terms of integration and inclusion. He associates the first with the concept of tolerance, while linking the other to the concept of full acceptance. ${ }^{6}$ European provisions and rules (e. g. the Luxembourg charter that speaks of a school for everyone) stress the significance of full participation in all areas of social life by persons with diverse disabilities. The UNESCO document of 2009 - Policy Guidelines on Inclusion in Education, reads: Inclusion is thus seen as a process of addressing and responding to the diversity of needs of all children, youth and adults through increasing participation in learning, cultures and communities, and reducing and eliminating exclusion within and from education..$^{7}$ According to the European Agency for Development in Special Needs Education, the key factors of inclusive education are considered to be the following: active participation of pupils in an education process that is understandable to them; supporting positive attitudes among persons engaged in the education of pupils with a broad range of education needs; proper teacher training; support for participation of pupils and parents when making decisions concerning the education process; development of an Individual Education Plan requir-

${ }^{5}$ P. Crispiani, System rehabilitacji i edukacji osób niepetnosprawnych we Włoszech, [in:] Społeczno-pedagogiczne konteksty niepełnosprawności, ed. by T. Żółkowska, wolumina@pl, Szczecin 2011, p. 123.

${ }^{6}$ V. Lechta, Pedagogika inkluzyjna, [in:] Pedagogika. T. 4, Subdyscypliny i dziedziny wiedzy o edukacji, ed. by B. Śliwerski, Gdańskie Wydawnictwo Pedagogiczne, Gdańsk 2010, pp. 321-335.

7 UNESCO, Policy Guidelines on Inclusion In Education, UNESCO, Paris 2009, p. 7. 
ing the utilisation of suitable didactic and educational strategies and solutions; development of a team action system based on cooperation of pupils, teachers, persons employed at the school, specialists and parents; learning and solving problems on the basis of cooperation with others; an individualised approach to every pupil; usage of an assessment system that would support the learning process. ${ }^{8}$ It is easy to notice that practically all factors are largely dependent on the teacher - both on the specialist teacher who should have the proper professional qualifications in terms of special education, competences and skills, but also the course teacher, who should also be required to have appropriate knowledge, competences, skills, properties or personal inclinations.

\section{The role and the tasks of special education paedagogues in public schools}

Issues concerning the functions, roles and tasks of special education paedagogues in public schools (including special and integration schools) is inseparably tied to issues related to vocational reparation, directives or demands related to the standards of education of teachers in terms of the future specialist paedagogues being equipped with relevant knowledge, skills, competences, as well as the implementation or verification of these in the school reality. The first part of these thoughts is devoted to the presentation of current laws governing the work of a teacher co-organising the education process for pupils with special education needs, to subsequently focus on an analysis of subject literature concerning the topic at hand on the basis of scientific views and an analysis of selected empirical studies.

In Poland, the status of support teacher is described in the newest Regulation of the Polish Minister of National Education of August 9th, 2017, on the conditions of organisation of education,

${ }^{8}$ European Agency for Development In Special Needs Education, Key principles for promoting quality in inclusive education - Recommendations for Policy Makers Odense, Denmark 2009, pp. 14-19. 
upbringing and care for children and youths who are disabled, socially maladapted and threatened by lack of social adaptation and the Regulation of the Polish Minister of National Education of August 25th, 2017, on the mode of keeping of documentation of teaching, education and care work by public preschools, schools and institutions, as well as the types of such documentation. At the same time it must be noted that beginning in January of 2016, on the basis of the Regulation of the Polish Minister of National Education of July 24th, 2015, on the conditions of arrangement of education, upbringing and care for children and youths with disabilities, social misadaptations and threatened by social misadaptation (Polish Journal of Laws of 2015 item no. 1113), changes were mate to the rules of employment of support teachers. Beforehand, in order for the indicated teacher to be employed, the consent was required of the authority running the institution. The Regulation of the Polish Ministry of Education of 2016 removed this requirement, thus transferring the decisive significance onto the recommendation of the certificate about the need of special education. The employment of a support teacher thus became obligatory for headmasters of public schools that are attended by pupils with the indicated certificates. Of course, it is the parents or legal custodians of the child who have the final say on the issue of the need to work with a support teacher.

According to the latest regulation of 2017, in addition, teachers are employed qualified in special education in order to co-organise the education process at preschools and public schools with integration departments, integration facilities as well as public preschools and schools, where special education covers pupils having certificates confirming the need of special education issued due to autism, including Asperger syndrome or multiple disabilities or others (in this case, with the consent of the operating authority). The Regulation further sets out the general tasks that a support teacher should execute in their work. ${ }^{9}$ The fundamental areas, to which the tasks of

\footnotetext{
${ }^{9}$ Regulation of the Polish Minister of National Education of August 9th, 2017 on the conditions of organisation of education, upbringing and care for children and
} 
the support teacher boil down, can be synthetically listed as: individualisation of the pupil's teaching process, or adaptation of the education requirements to their individual needs on the basis of recommendations indicated in the certificate issued by an education and psychological counselling facility or a different special counselling facility (adaptation of curriculum content, of forms and resources of work, of the modes of evaluation), aid for and cooperation with teachers, parents and other specialists and entities related to the pupil's education, execution of re-validation, social therapy, re-socialisation activities, drawing up and keeping of relevant documentation of the child (e. g. certificates concerning the need for special education, general assumptions for therapeutic and revalidation work as developed individually for every child, opinions, descriptive evaluations that are attached to the end-of-term and end-of-year grades, including a multi-speciality evaluation of the pupil's level of functioning. In addition, the teacher co-organising education should keep a journal, where they record their weekly agenda of activities and activities from the individual days, including information about contact with persons and institutions, with which they cooperate when executing their duties. ${ }^{10}$

Analysing the subject literature with respect to the functions and tasks of special paedagogues, one must be reminded of the views of one of the forerunners of Polish special education - Otton Lipkowski. He paid particular attention to specific education activities that should emerge in the education and upbringing process, such as: cooperation of the public school with psychological and paedagogi-

youths who are disabled, socially unadapted and threatened by lack of social adaptation, $\S 5$ p. 4, § 6, § 7 Polish Journal of Laws of 2017, item no. 1578; conf. also: R. Cybulska, H. Derewlana, A. Kacprzak, K. Pęczek, Uczeń ze specjalnymi potrzebami edukacyjnymi w świetle nowych przepisów prawa oświatowego, Ośrodek Rozwoju Edukacji, Warszawa 2017, pp. 7-9 and pp. 58-70.

${ }^{10}$ Regulation of the Polish Minister of National Education of August 25th, 2017 on the mode of keeping of documentation of teaching, education and care work by public preschools, schools and institutions, as well as the types of such documentation, § 18, § 19 Polish Journal of Laws of 2017, item no. 1646. 
cal counselling facilities or therapeutic facilities; cooperation with the closest family, should an improper family environment be the cause of the pupil's wrong development; organisation at the public school of individual aid for persons with learning difficulties; organisation of education teams; offering of corrective exercise in the area of speech therapy, posture, motor development. ${ }^{11}$ Without a doubt, these are clear suggestions describing the need to act in terms of education in order to include pupils with development and education difficulties to the functioning of the school. Lipkowski also assigned much significant to functions of dynamisation that should characterise the entire didactic and education process of pupils with learning difficulties, for the implementation of which teachers should be responsible. These functions are: stimulation, acceleration, compensation or culture creation ${ }^{12}$. Studies concerning the functions of support teachers and their actual implementation in school practice were conducted by Magdalena Korneluk and Milena Nazarczuk. The studies were conducted on a group of 42 support teachers working at integration classes of primary schools and schools above the primary level in Siedlce, Poland. The authors were able to show that the majority of tasks and functions were actually executed by the support teachers. The most commonly indicated tasks of special paedagogues were: development and preparation of education aids for able pupils as well as organisation of good cooperation with the pupil's home environment. The greatest difficulties and problems encountered by the studied support teachers in their work are: insufficient teaching aids for pupils with special education needs, incorrect attitudes of healthy pupils with respect to the disabled, undesirable behaviour of disabled pupils, difficulty understanding teacher commands by pupils, attention focus deficiencies, difficulty communicating with the disabled pupil. Data acquired by the study authors also showed that the majori-

11 O. Lipkowski, Pedagogika specjalna, Wydawnictwo PWN, Warszawa 1981, p. 107.

12 O. Lipkowski, Pedagogika specjalna, Wydawnictwo PWN, Warszawa 1981, p. 18. 
ty of support teachers noted the need of change of attitudes with respect to the special paedagogue, because, in their opinion, this work is in many cases not appreciated. The majority of support teachers also did not satisfactorily evaluate their cooperation with the remainder of the teachers at the school, indicating that it frequently lacks partnership, understanding and respect. ${ }^{13}$ Within the context of the quoted study results, a further interesting study conducted in the year 2013 in the Świętokrzyskie Voivodeship of Poland may also be presented here, analysed in the article entitled Mainstream school as a meeting space of teachers and special educators promoting the idea of inclusive education, by Mirosław Rutkowski and Karol Bidziński. The researchers write, among others, about special paedagogues as (un) necessary specialists, using the following argumentation: the analysed support teachers had professional qualifications gained mainly through qualification courses, to a lesser extent in course of post-diploma or field-specific studies, in addition, they were educated according to the biomedical disability model, and evaluating their material and methodical competences, they primarily indicated preparation for work with persons with intellectual disabilities, evaluating much lower their diagnostic, planning, execution or evaluation competences with respect to support for the development of pupils with special education needs that stemmed from social misadaptation, risks of social misadaptation, pupils with special learning difficulties or particularly gifted pupils. The results of tests conducted among 405 teachers of public schools indicated limited effectiveness and availability of support by special paedagogues for course teachers. The respondents expressed the opinion that a special paedagogue is not necessary as an important and effective source of support. Teachers of public schools themselves did not feel competent to work with pupils with individual education needs that stemmed from disability. They saw the cause in the lack

${ }^{13}$ M. Korneluk, M. Nazarczuk, Zakładane i realizowane funkcje nauczycieli wspomagajacych w klasie integracyjnej, "Student Niepełnosprawny. Szkice i Rozprawy" 2008, no. 8(1), pp. 189-215. 
of sufficient preparation during studies. In their conclusions, the authors of the quoted study noted that communication difficulties, deficiencies in terms of professional competences and primarily lack of full consent to the idea of implementation of inclusive education can form a barrier in the establishment of a community of teachers of public schools and special paedagogues. ${ }^{14}$

Within the context of thoughts on the professional competences of special paedagogues (including future support teachers), particular attention needs to be paid to the aspect of competences. This describes both competences related to knowledge in the area of special education, psychological and paedagogical, diagnostic, therapeutic, education and didactic competences, but also personal competences (related to personal traits and dispositions) or finally social and emotional competences. In her study, Anna Zamkowska - referring, among others, back to Aleksandra Maciarz and studies on these issues - writes about dispositions to work as a support paedagogue and properties characterising successful teachers in the area of inclusive education. Such persons should have a suitable scope of knowledge about the different categories of disabilities, but also the skills to provide care, educate and teach disabled children and youths, express positive emotional attitudes with respect to them, be characterised by sensitivity to a pupil's individual needs and be convinced about the value of inclusive education and teaching of children and youths with special education needs. In addition, special paedagogues working within inclusive education should have such personal traits as: patience, perseverance, a good attitude, resistance to stress. ${ }^{15}$ Danuta Al-Khamisy indicates the need to perfect the following competences and skills among inclusive education

${ }_{14}$ M. Rutkowski, K. Bidziński, Szkoła ogólnodostępna przestrzenia spotkania nauczycieli i pedagogów specjalnych - realizatorów idei edukacji włączającej, "Niepełnosprawność. Dyskursy pedagogiki specjalnej” 2018, no. 29, pp. 43-65.

15 A. Zamkowska, Kompetencje nauczyciela wymagane w pracy $z$ uczniem $z$ niepetnosprawnością umysłowa w procesie edukacji inkluzyjnej, [in:] Kompetencje pedagoga specjalnego. Aktualne wyzwania teorii i praktyki, ed. by Z. Palak, A. Bujnowska, Wydawnictwo Uniwersytetu Marii Curie-Skłodowskiej, Lublin 2008, pp. 79-88. 
teachers: the ability to recognise and satisfy diverse education needs of pupils; the attitude of openness to cooperation with pupils' parents and families; the ability to work in a team facilitating efficient cooperation with other teachers and specialists both at the school as well as outside of it. ${ }^{16}$ Diagnostic studies concerning the feeling of professional competences to work with a disabled pupil among early school education teachers were conducted by Marta Uberman and Aleksandra Mach. The authors adopted the qualification of professional competences suggested by Aniela Korzon (praxeological competences, communication competences, creative competences), taking into account material and methodical preparation of teachers to work with disabled pupils, as stressed by the Polish Ministry of Education in the professional competence standards. The study was conducted in 2015 at 19 public schools from the subcarpathian voivodeship region. The researchers used an original tool - the scale of assessment of own competences in didactic and education work with a disabled pupil and a survey questionnaire, which is also proprietary. The results acquired by the study authors indicated that $75 \%$ of those surveyed consider their own professional competences and the preparation for work with a disabled child as being average. Similar results were obtained for all three distinguished competences. As it turns out, teachers were fully aware that their knowledge and skills are insufficient to efficiently work with disabled pupils. ${ }^{17}$

16 D. Al-Khamisy, Ksztatcenie uczniów ze specjalnymi potrzebami edukacyjnymi w powszechnym systemie oświatowym, [in:] Dydaktyka specjalna w przygotowaniu do kształcenia uczniów ze specjalnymi potrzebami edukacyjnymi. Podręcznik akademicki, ed. by J. Głodkowska, Wydawnictwo Akademii Pedagogiki Specjalnej, Warszawa 2012, pp. 113-139.

${ }_{17}$ M. Uberman, A. Mach, Kompetencje nauczyciela edukacji wczesnoszkolnej w szkole ogólnodostępnej w pracy z dzieckiem z niepetnosprawnościa, „Lubelski Rocznik Pedagogiczny" 2016, vol. XXXV, issue 3, pp. 165-185; Conf. also studies by Krystyna Barłóg (e.g. quoted in papers by M. Uberman and A. Mach), the subject of which is support the development of children with minor intellectual disabilities in diverse early education forms. These studies also applied to the area of competences. The results acquired by this researcher disclosed that public school teachers assessed their 
The success of the idea of inclusive education is doubtless based on good cooperation of support teachers with teachers of the specific course. In this regard, of significant importance are attitudes towards pupils with individual needs, the conviction concerning the justification of joint teaching of all pupils, relevant knowledge and professional preparation of this second group of teachers as well. The particular situation that teachers of public schools who are not special paedagogues are in, is described by Dorota Krzemińska and Krystyna D. Rzedzicka in the article entitled, On vocational schooling of special educators' - the (un)changed landscape? In course of a thorough analysis of object literature (including an analysis of published empirical studies) the authors conclude that public school teachers who are not special educators are not enthusiastic towards inclusive education, that in course of their own vocational preparation they did not acquire knowledge and competences to work with disabled pupils, that they express ignorance of basic concept systems related to the classification of the disabled, their integration, diagnosis, preventive care, focusing mainly on deficiencies related to the limited abilities of pupils, are characterised by ambiguity in terms of evaluation of pupils with special education needs and lack of creativity in the activities undertaken with respect to them. ${ }^{18}$

\section{Assumptions and analysis of own research}

The own research presented in this study are a fragment of a larger empirical undertaking, the subject of which were made broadly understood issues of the work of the teacher co-organising the process of education of pupils with special education needs in

competences decidedly lower than special and integration school teachers - see K. Barłóg, Wspomaganie rozwoju dzieci z niepetnosprawnością intelektualna w stopniu lekkim w różnych formach edukacji wczesnoszkolnej, Wydawnictwo Uniwersytetu Rzeszowskiego, Rzeszów 2008.

18 D. Krzemińska, K.D. Rzedzicka, O przygotowaniu zawodowym pedagogów specjalnych-krajobraz (bez)zmian?, „Niepełnosprawność” 2009, no. 1, pp. 113-124. 
public education. The mentioned research project was planned on the basis of a quantitative and qualitative research strategy - "(..) consideration in social (education) research of diverse points of view, expressed mainly by the fusion of quantitative and qualitative methods (as being complementary with respect to each other), as recommended by Polish paedagogues and specialists in the area of education methodolo$g y^{\prime \prime} .{ }^{19}$ The study presented here are a pilot study, introductory research, the fundamental objective of which - as it was assumed to be in the form of a diagnostic study - was to get to know only a certain section of the research reality, meaning, the opinion of special educators and other public school teachers (early school education teachers and course-specific teachers) on the work (roles, tasks, properties and personal dispositions) of teachers co-organising the process of education of pupils holding certificates on the need of special education. The own research uses a proprietary survey questionnaire, constructed mainly on the basis of closed and semi-open question and answer systems. During the planning and construction stage of the tool, attention was given to include criteria of psychometric quality, e.g. objectivity, standardisation, aptness. ${ }^{20}$ The questions of the survey, aimed at the studied teachers, are focused on such areas as: I. Professional qualifications of the analysed teachers; II. Working with pupils with special education needs; III. Skills, personal dispositions.

The research problems took the form of the following questions:

1. What are the properties of the work (the role and tasks) of a teacher co-organising the process of education of pupils with certificates on the need for special education at the studied public schools?

2. What aspects in particular are related to the role and tasks of a support teacher that are the most important success factors of didactic and education work with pupils with special education needs as

${ }^{19}$ W. Dróżka, Triangulacja badań. Badania empiryczne ilościowo - jakościowe, [in:] Podstawy metodologii badań w pedagogice, ed. by S. Palka, Gdańskie Wydawnictwo Psychologiczne, Gdańsk 2010, p. 134.

${ }^{20}$ Conf. E. Hornowska, Testy psychologiczne - teoria i praktyka, Wydawnictwo Scholar, Warszawa 2007, pp. 25-32. 
evaluated by teachers conducting classes, including from the point of view of support teachers themselves?

3. In the opinion of the analysed teacher groups, which competences, skills, personal properties should a support teacher have?

Table 1. Professional qualifications of surveyed support teachers

\begin{tabular}{|c|c|c|c|c|}
\hline \multirow{2}{*}{ Main education } & \multicolumn{2}{|c|}{$\begin{array}{l}\text { Support } \\
\text { teachers }\end{array}$} & \multirow{2}{*}{$\begin{array}{c}\text { Post-diploma studies, } \\
\text { qualification courses, } \\
\text { others }\end{array}$} & \multirow{2}{*}{$\begin{array}{c}\text { Support teachers } \\
\mathrm{N}\end{array}$} \\
\hline & $\mathrm{N}$ & $\%$ & & \\
\hline Early education & 12 & 25 & Oligophrenic paedagogy & 28 \\
\hline $\begin{array}{l}\text { Early education with oligophre- } \\
\text { nic paedagogy }\end{array}$ & 3 & 6 & Surdopedagogy & 27 \\
\hline Care and education paedagogy & 3 & 6 & Tyflopedagogy & 19 \\
\hline Resocialisation paedagogy & 1 & 2 & Speech therapy & 10 \\
\hline $\begin{array}{l}\text { Education in the subject being } \\
\text { taught }\end{array}$ & 21 & 44 & $\begin{array}{l}\text { Post-diploma studies on } \\
\text { working with pupils with } \\
\text { ASD }\end{array}$ & 26 \\
\hline Oligophrenic paedagogy & 7 & 15 & \begin{tabular}{|l|}
$\begin{array}{l}\text { Resocialisation and so- } \\
\text { ciotherapy }\end{array}$ \\
\end{tabular} & 11 \\
\hline $\begin{array}{l}\text { Special paedagogy within reso- } \\
\text { cialisation }\end{array}$ & 1 & 2 & Others & 40 \\
\hline Total: & 48 & 100 & - & $\begin{array}{l}161{ }^{*} \text { most teachers have } \\
\text { more than one addi- } \\
\text { tional education unit. }\end{array}$ \\
\hline
\end{tabular}

Source: Own work.

The study was conducted between February and April of 2019. Initially, 205 surveys were distributed among teachers and special educators working at public schools in the regions of Silesia and Dąbrowa Basin of Poland. As a result, 102 returned and completed surveys were analysed. The study covered 48 support teachers and 54 teachers not being support teachers (early school education teachers and 2nd education stage teachers) from 10 public primary schools (entities from the localities of Katowice, Siemianowice Śląskie, 
Sosnowiec, Będzin and Czeladź). Among support teachers, women made up $92 \%$ of those surveyed, the remaining $8 \%$ being men. Among the studied teachers not being support teachers, $76 \%$ were women and $24 \%$ men. The highest share in both groups were nominated and certified teachers, there were almost $74 \%$ of all teachers participating in the study, whereby in the group of support educators - there were slightly more nominated teachers - $21(44 \%)$ than certified teachers $(17$, or $35 \%)$. The opposite tendency was found in the group not being support teachers, with the most being certified teachers, at $36 \%$, followed by nominated teachers, $33 \%$.

In terms of preparation for working in the profession, the studied support teachers acquired their qualifications in the area of special education mainly during post-diploma studies and additional qualification courses. The main education of the majority of support teachers is related to the course or subject they teach, at $44 \%$ and in the area of early education, at $25 \%$, totalling at approx. $70 \%$ of the studied group. A much lower percentage (25\% in all) are special educators "from the outside", the main field of whom is special paedagogy or one of its subfields. In terms of additional education in the form of post-diploma studies, qualification courses, the studied support teachers frequently have more than one specialisation. The conducted study also shows that the majority of the analysed teachers presently only work with a single pupil certified to be in need of special education. There were 12 teachers who indicated working with more than one pupil needing support, which made up $25 \%$ of all those surveyed in this group. The majority of teachers work with pupils with autism spectrum disorders - 22 persons, the least work with pupils with multiple disabilities - four teachers. In addition, 34 of the surveyed teachers offer re-evaluation classes and 16 teachers hold socio-therapeutic and resocialisation classes.

In the area of questions related to the work of teachers with pupils with special education needs, these were categorised. Such aspects were distinguished as: 1.) Execution of general tasks; 2.) Cooperation with the course teacher; 3 .) Cooperation with the pupil's parents; 4.) Most common barriers and difficulties in the work of 
a support teacher. The studied teachers chose one of many suggested responses concerning the individual aspects related to the role and the tasks of a support teacher. They were to indicate that particular response that they believed to be most significant from the point of view of inclusivity of their work and the success of inclusive education.

Table 2. Execution of tasks of a support teacher - most common responses by the studied teachers

\begin{tabular}{|l|l|c|l|l|}
\hline \multicolumn{1}{|c|}{$\begin{array}{c}\text { Task execution } \\
\text { aspects }\end{array}$} & \multicolumn{1}{|c|}{$\begin{array}{c}\text { Responses of support } \\
\text { teachers }\end{array}$} & $\%$ & $\begin{array}{l}\text { Responses by teachers not } \\
\text { being support teachers }\end{array}$ & $\%$ \\
\hline Within general tasks & $\begin{array}{l}\text { Correct selection of methods, } \\
\text { forms and resources to work } \\
\text { with the pupil. }\end{array}$ & 73 & $\begin{array}{l}\text { Supporting the teachers } \\
\text { with professional know- } \\
\text { ledge }\end{array}$ & 79 \\
\hline $\begin{array}{l}\text { Within cooperation } \\
\text { with the course } \\
\text { teacher }\end{array}$ & $\begin{array}{l}\text { Cooperation in terms of de- } \\
\text { termining the scope of edu- } \\
\text { cation adaptations for the } \\
\text { pupil. }\end{array}$ & 76 & $\begin{array}{l}\text { In cooperation with the } \\
\text { course teacher } \text { - determina- } \\
\text { tion of work during the } \\
\text { class }\end{array}$ & 74 \\
\hline $\begin{array}{l}\text { Within cooperation } \\
\text { with the pupil's } \\
\text { parents }\end{array}$ & $\begin{array}{l}\text { Inclusion of parents to } \\
\text { cooperate with the school, } \\
\text { the special education facility }\end{array}$ & 61 & $\begin{array}{l}\text { Supporting the parents with } \\
\text { professional knowledge }\end{array}$ & 63 \\
\hline $\begin{array}{l}\text { Barriers, difficulties } \\
\text { encountered in } \\
\text { work }\end{array}$ & Contact with the parents & 53 & $\begin{array}{l}\text { Lack of support teacher } \\
\text { skills to cope with undesir- } \\
\text { able behaviour, aggression } \\
\text { of the pupil. }\end{array}$ & 56 \\
\hline
\end{tabular}

Source: Own work.

As table 2 shows, teacher responses indicate various choices. It seems that for public school teachers, specific activities undertaken by support teachers are the most important. They expect aid, knowledge and specific solutions to difficulties or problems that emerge in course of work with a pupil requiring particular support. They also indicate that they are the leaders when it comes to the class education process conducted together with the support teacher. Support teachers, in turn, in their most frequent responses focused 
mainly on the needs of pupils, mainly stressing the adaptation of all those components of the education process that are able to satisfy the needs of pupils and their capacities as optimally as they can. Within the scope of activities in concert with the course teacher, they appreciate the cooperation component, hence, common engagement in the process of requirement adaptation.

The ultimate area of the study applied to personal skills and traits that should characterise a support teacher. In the view of support teachers, the key skill should be identification and accentuation of a pupil's strong suits - $62 \%$ of those surveyed; course teachers considered the most desired skill to be the ability to motivate the pupil $59 \%$ of those surveyed. Among personal traits, support teachers most frequently indicated: understanding the pupil's needs $51 \%$, empathy $31 \%$, and teachers from the second surveyed group indicated such properties as communication ability $42 \%$ and patience $38 \%$.

\section{Discussion of the own survey results and conclusions}

The key conclusions from the conducted studies, at the same time forming responses to the formulated research problems, can be summarised as follows: 1 . Only $25 \%$ of the analysed support teachers have special paedagogy as their leading field of education. In most cases these are early education teachers or course teachers who acquired their special education licences during post-diploma studies and in course of post-diploma and additional qualification courses. 2. Considering the execution of roles and tasks that are of significant importance for inclusive education, support teachers considered the following to be the most important: correct choice, preparation and adaptation of education material for pupils, cooperation with course teachers in terms of determination of the education adaptations for pupils, inclusion of parents to cooperate with the school; however, in terms of the encountered barriers and difficulties, it was specifically contact with teachers that turned out to be the most difficult for the educators who were surveyed. At the same 
time, the group of teachers not being support teachers declared the following choices: professional knowledge aid provided to them by support teachers, joint determination of activities during classes (one should consider the motivation for this choice; perhaps the case concerns the will to maintain a "dominant" position of teachers holding classes, for whom it is important that the course of the class be consulted), support for teachers with the professional knowledge of support teachers (this selection would suggest the will to transfer responsibility for contacts with parents of "difficult" pupils to support teachers; this would require further study), in the aspect of the encountered barriers and difficulties in the work of the support teacher; the second group of respondents indicated lack of ability of special educators to cope with undesirable behaviour, with pupil aggression (this may suggest the need to take "a closer look" and more thoroughly analyse curricula for special educators - how are special educators prepared to handle difficult situations, what is their actual knowledge on the diverse signs of behaviour disturbances, etc.; are there courses on this topic in their study curriculum and what is their volume?). 3 . The studied teachers considered considered diagnostic skills concerning the recognition of strong suits of pupils to be the most significant skill that should characterise a support teacher; course teachers indicated the ability to motivate pupils as such a skill. In both groups, the studied teachers considered properties such as empathy, communication, patience, understanding pupil needs to be important in the work of a support teacher. Within the context of the acquired results of own studies, quoted should be here the study by Maria Flanczewska-Wolny and Jerzy Wolny of 2017. Using their survey questionnaire, the researchers studied a group of 51 teachers in public education (the study spanned teachers from one primary school and two lower secondary schools), also from the territory of the Silesian Voivodeship. The survey asked public school teachers to express their attitude towards tasks to be executed by special paedagogues. The acquired results showed that the activity forms of support teachers considered most important by the respondents should include those that 
are to reduce as strongly as possible difficulties related to the fact of a disabled pupil being a member of the class, so as to ensure that they are able to conduct their class without excess disturbances, which would align with the results of own research presented above. However, further findings of the researchers fail to align with the results of the study acquired by the author of the present paper. The studied teachers largely failed to notice the value related to professional support by special educators, the ability to "make use" of their competence resources or special knowledge about the details of diverse disturbances, even for the purpose of expansion of their own skills and professional development. ${ }^{21}$

The presented own research absolutely does not exhaust the issues at hand. It only applies to a minor aspect of the important issue that currently is the role of special educators in the inclusive education system. They do not allow any overly general conclusions, even for the reason of the relatively minor research group. They certainly require further, more detailed exploration and analyses expanded also to include parents and pupils, as well as the usage of methods, techniques and tools characteristic for quality strategies in the study. ${ }^{22}$ They can constitute a contribution to the ever open scientific discourse in the mentioned field, e. g.:

- with respect to issues of elevation of the status of support teacher and of their work in public education ${ }^{23}$;

${ }^{21}$ M. Flanczewska-Wolny, J. Wolny, Pedagog specjalny-asystent ucznia z niepetnosprawnością w szkole ogólnodostępnej w opiniach nauczycieli, [in:] Wybrane konteksty i wyzwania współczesnej pedagogiki specjalnej, ed. by K. Barłóg, Wydawnictwo Uniwersytetu Rzeszowskiego, Rzeszów 2017, pp. 228-241.

22 As noted in the chapter on assumptions to the own work - the author of the present study continues work in the discussed scope.

${ }^{23}$ A reference may be provided among Scandinavian countries, such as e.g. Finland, considered to be a country with one of the best education systems and showing great success in education of disabled pupils, where teaching is a profession held in high esteem. Only $10 \%$ of candidates are accepted to study to become teachers, and the recruitment procedure ahead of studies is bi-level, checking dispositions of the study candidates in many areas - see D. Mitchell, Sprawdzone metody w edukacji specjalnej i wtaczajacej. Strategie nauczania poparte badaniami, Wydawnictwo Harmonia Universalis, Gdańsk 2016, pp. 371-379. 
- issues related to vocational preparation of future special educators, the standards of their teaching 24 , the quality of curricula, also during post-diploma studies;

- issues related to paedagogical preparation of public school teachers (in particular course teachers), the number of modules and the duration of classes in special education;

- as part of the working methods of teachers co-organising education, issues related to the introduction of new content expanding upon the skill of broadly understood cooperation; beside methodical competences the development of social, emotional, education skills that would permit differentiation between the functions of re-validator and educator.

\section{Bibliography}

[1] Al-Khamisy D., Ksztatcenie uczniów ze specjalnymi potrzebami edukacyjnymi w powszechnym systemie oświatowym, [in:] Dydaktyka specjalna w przygotowaniu do kształcenia uczniów ze specjalnymi potrzebami edukacyjnymi. Podręcznik akademicki, ed. by J. Głodkowska, Wydawnictwo Akademii Pedagogiki Specjalnej, Warszawa 2012, pp. 113-139.

[2] Barłóg K., Wspomaganie rozwoju dzieci z niepetnosprawnościa intelektualna w stopniu lekkim w różnych formach edukacji wczesnoszkolnej, Wydawnictwo Uniwersytetu Rzeszowskiego, Rzeszów 2008.

[3] Crispiani P., System rehabilitacji i edukacji osób niepetnosprawnych we Włoszech, [in:] Społeczno-pedagogiczne konteksty niepetnosprawności, ed. by T. Żółkowska, wolumina@pl, Szczecin 2011, p. 123.

[4] Chrzanowska I., Nauczanie inkluzyjne w doświadczeniach polskich - podstawy prawne i społeczne uwarunkowania, „Studia Edukacyjne” 2014, no. 30, pp. 109-117.

[5] Cybulska R., Derewlana H., Kacprzak A., Pęczek K., Uczeń ze specjalnymi potrzebami edukacyjnymi w świetle nowych przepisów prawa oświatowego, Ośrodek Rozwoju Edukacji, Warszawa 2017.

[6] Cytowska B., Przeglad badań empirycznych nad inkluzja w edukacji, „Problemy Edukacji, Rehabilitacji i Socjalizacji Osób Niepełnosprawnych" 2016, no. 22/1, pp. 189-213.

${ }^{24}$ Information on the guidelines for the new teacher education standards can be found in the work by M. Sekułowicz, Nowe standardy ksztatcenia nauczycieli - ich cel, rola, zadania i dylematy realizacyjne, <https://www.kul.pl/files/581/Wydzial/KRK/ dobre_praktyki/FREiSW/Sekulowicz.pdf> [access: 19.05.2019]. 
[7] Dróżka W., Triangulacja badań. Badania empiryczne ilościowo-jakościowe, [in:] Podstawy metodologii badań w pedagogice, ed. by S. Palka, Gdańskie Wydawnictwo Psychologiczne, Gdańsk 2010, pp. 124-135.

[8] European Agency for Development In Special Needs Education, Key principles for promoting quality in inclusive education - Recommendations for Policy Makers, Odense, Denmark 2009, pp. 14-19.

[9] Firkowska-Mankiewicz A., Szumski G., Idea integracyjnego kształcenia i edukacji włączajacej w polskiej pedagogice, [in:] „Pedagogika specjalna, podręcznik akademicki” vol. 2, ed. by D.D. Smith, A. Firkowska-Mankiewicz, G. Szumski, Wydawnictwo Akademii Pedagogiki Specjalnej, Wydawnictwo Naukowe PWN, Warszawa 2008, pp. 319-346.

[10] Flanczewska-Wolny M., Wolny J., Pedagog specjalny-asystent ucznia z niepetnosprawnością w szkole ogólnodostępnej w opiniach nauczycieli, [in:] Wybrane konteksty i wyzwania wspótczesnej pedagogiki specjalnej, ed. by K. Barłóg, Wydawnictwo Uniwersytetu Rzeszowskiego, Rzeszów 2017, pp. 228-241.

[11] Gajdzica Z., Opinie nauczycieli szkót ogólnodostępnych na temat edukacji włączajaccej uczniów z lekkim upośledzeniem umystowym w kontekście toczącej się reformy ksztatcenia specjalnego, [in:] Uczeń z niepetnosprawnościa w szkole ogólnodostępnej, ed. by Z. Gajdzica, Wydawnictwo Wyższej Szkoły Humanitas, Sosnowiec 2011, pp. 56-79.

[12] Głodkowska J., W poszukiwaniu modelu edukacji właczajacej, „Meritum” 2009, no. 2, pp. 5-8.

[13] Hornowska E., Testy psychologiczne - teoria i praktyka, Wydawnictwo Scholar, Warszawa 2007, pp. 25-32.

[14] Janiszewska-Nieścioruk Z., (Nie)dojrzałość proinkluzyjnych zmian w kształceniu osób z niepetnosprawnościq, „Niepełnosprawność. Dyskursy pedagogiki specjalnej" 2016, no. 22, pp. 47-59.

[15] Korneluk M., Nazarczuk M., Zakładane i realizowane funkcje nauczycieli wspomagajacych w klasie integracyjnej, „Student Niepełnosprawny. Szkice i Rozprawy" 2008, no. 8(1), pp. 189-215.

[16] Krause A., Wspótczesne paradygmaty pedagogiki specjalnej, Oficyna Wydawnicza „Impuls”, Kraków 2011.

[17] Kruk-Lasocka J., Dostrzec dziecko z perspektywy edukacji właczajacej. Wydawnictwo Naukowe Dolnośląskiej Szkoły Wyższej, Wrocław 2012.

[18] Krzemińska D., Rzedzicka K.D., O przygotowaniu zawodowym pedagogów specjalnych - krajobraz (bez)zmian?, „Niepełnosprawność” 2009, no. 1, pp. 113-124.

[19] Lechta V., Pedagogika inkluzyjna, [in:] Pedagogika. T. 4, Subdyscypliny i dziedziny wiedzy o edukacji, ed. by B. Śliwerski, Gdańskie Wydawnictwo Pedagogiczne, Gdańsk 2010, pp. 321-335.

[20] Lipkowski O., Pedagogika specjalna, Wydawnictwo PWN, Warszawa 1981. 
[21] Mitchell D., Sprawdzone metody w edukacji specjalnej i wtączającej. Strategie nauczania poparte badaniami, Wydawnictwo Harmonia Universlis, Gdańsk 2016.

[22] Regulation of the Polish Minister of National Education of August 9th, 2017 on the conditions of organisation of education, upbringing and care for children and youths who are disabled, socially unadapted and threatened by lack of social adaptation, § 5 p. 4, § 6, § 7 Polish Journal of Laws of 2017, item no. 1578.

[23] Regulation of the Polish Minister of National Education of August 25th, 2017 on the mode of keeping of documentation of teaching, education and care work by public preschools, schools and institutions, as well as the types of such documentation, § 18, § 19 Polish Journal of Laws of 2017, item no. 1646.

[24] Rutkowski M., Bidziński K., Szkoła ogólnodostępna przestrzenia spotkania nauczycieli i pedagogów specjalnych - realizatorów idei edukacji wtaczającej, „Niepełnosprawność. Dyskursy pedagogiki specjalnej" 2018, no. 29, pp. 43-65.

[25] Sekułowicz M., Nowe standardy kształcenia nauczycieli - ich cel, rola, zadania i dylematy realizacyjne, <https://www.kul.pl/files/581/Wydzial/KRK/dobre_prakty ki/FREiSW/Sekulowicz.pdf> [access: 19.05.2019].

[26] Szumski G., współ. Firkowska-Mankiewicz A., Wokót edukacji włączającej. Efekty ksztatcenia uczniów z niepetnosprawnościa intelektualna w stopniu lekkim w klasach specjalnych, integracyjnych i ogólnodostępnych, Wydawnictwo Akademii Pedagogiki Specjalnej, Warszawa 2010.

[27] Szumski G., Edukacja włączająca - niedokończony projekt, "Ruch Pedagogiczny” 2014, no. 4, pp. 127-139.

[28] Uberman M., Mach A., Kompetencje nauczyciela edukacji wczesnoszkolnej w szkole ogólnodostępnej w pracy z dzieckiem z niepetnosprawnościa, „Lubelski Rocznik Pedagogiczny" 2016, vol. XXXV, issue 3, pp. 165-185.

[29] UNESCO, Policy Guidelines on Inclusion In Education, UNESCO, Paris 2009, pp. 7-9.

[30] Zacharuk T., Wtaczajaca edukacja, [w:] Encyklopedia Pedagogiczna XXI w., vol. VII, ed. by T. Pilch, Wydawnictwo Akademickie „Żak”, Warszawa 2008, pp. 167-173.

[31] Zamkowska A., Kompetencje nauczyciela wymagane w pracy $z$ uczniem z niepetnosprawnościa umystowa w procesie edukacji inkluzyjnej, [in:] Kompetencje pedagoga specjalnego. Aktualne wyzwania teorii i praktyki, ed. by Z. Palak, A. Bujnowska, Wydawnictwo Uniwersytetu Marii Curie-Skłodowskiej, Lublin 2008, pp. 79-88. 